\title{
PIRMINIS HIPERALDOSTERONIZMAS: ETIOLOGIJA, DIAGNOSTIKA IR GYDYMAS
}

\author{
Donatas Savičius \\ Vilniaus universitetas, Medicinos fakultetas
}

Raktažodžiai: aldosteronas, hiperaldosteronizmas, hiperaldosteronizmo etiologija, diagnostika ir gydymas.

\section{Santrauka}

Apskaičiuota, kad pirminis aldosteronizmas yra pagrindinè arterinès hipertenzijos priežastis $>10$ proc. pacientu. Lyginant pirmine arterine hipertenzija ir pirminio hiperaldosteronizmo sukelta arterine hipertezija sergančius pacientus pagal amžių ir lytị, hiperaldosteronizmo sukelta hipertenzija pasižymi didesne mirties nuo kraujagyslių ir širdies ligų rizika. Pirminio hiperaldosteronizmo diagnostikos principas - pacientų atranka, diagnozès patvirtinimas ir hiperaldosteronizmo potipių klasifikavimas. Pirminio hiperaldosteronizmo gydymo esmè - aldosterono hipersekrecijos ir jo sukeltos hipertenzijos kontrolè bei inkstų ir širdies-kraujagyslių sistemų pažeidimo prevencija. Tyrimo tikslas - išanalizuoti ir aptarti įrodymais pagrịstą informaciją apie hiperaldosteronizmo etiologiją, diagnostiką ir gydymą.

\section{Ivadas}

Aldosteronas - antinksčiu žievės kamuolinès srities (lot. zona glomerulosa) gaminamas mineralkortikosteroidas, veikiantis mineralkortikosteroidų receptorius, esančius inkstų distaliniuose kanalëliuose, prakaito ir seilių liaukose bei žarnyno gleivinëje. Pagrindinis veikimo mechanizmas $\mathrm{Na}+/ \mathrm{K}+$ siurblio aktyvavimas - aldosteronas skatina $\mathrm{Na}+$ reabsorbciją bei $\mathrm{K}+$ ir $\mathrm{H}+$ sekreciją. Dėl aldosterono poveikio vystosi hipervolemija, pakyla kraujospūdis ir didèja kalio ekskrecija su šlapimu. Hiperaldosteronizmo metu esantis aldosterono perteklius sukelia hipertenziją, hipokalemiją, hipernatremiją ir metabolinę alkalozę. Apskaičiuota, kad pirminis hiperaldosteronizmas (PHA) yra pagrindinè arterinès hipertenzijos priežastis $>10$ proc. pacientų [1]. Lyginant pirmine arterine hipertenzija ir hiperaldosteronizmo sukelta arterine hipertezija sergančius pacientus pagal amžiu ir lyti, hiperaldosteronizmo sukelta hipertenzija pasižymi didesne mirties nuo kraujagyslių ir širdies ligų rizika [2]. Hiperaldosteronizmo gydymo esmé - aldosterono hipersekrecijos ir jo sukeltos hipertenzijos kontrolè bei inkstų ir širdies-kraujagyslių sistemų pažeidimo prevencija [3].

Tyrimo tikslas - išanalizuoti ir aptarti ịrodymais pagrịstą informaciją apie hiperaldosteronizmo etiologiją, diagnostiką ir gydymą.

\section{Tyrimo medžiaga ir metodai}

Taikyta sisteminè mokslinès literatūros bei dokumentų apžvalga ir analizė. Duomenų buvo ieškoma Google Scholar, UpToDate, Cochrane bei Medline (PubMed) duomenų bazèse. Visateksčiai straipsniai atrinkti, jei jų pavadinimas, santrauka ar reikšminiai žodžiai nurode, kad tyrimas tinkamas įtraukti i šią apžvalgą. Pasirinktos tik anglų kalba skelbtos publikacijos. Vartoti nurodyti raktažodžiai. Atrinkti, išanalizuoti ir apibendrinti 8 straipsniai.

\section{Tyrimo rezultatai}

Etiologija. Pagal aldosterono sekrecijos sutrikimo priežastị, hiperaldosteronizmas skirstomas ị pirminị ir antrinį. PHA - autonominis aldosterono hipersekrecijos sutrikimas, nepriklausantis nuo renino aktyvumo. Dažniausios PHA priežastys - abipuse antinksčiu hiperplazija (60\%) ir vienpusė antinksčiu adenoma (35\%), retesnès PHA formos - šeiminis aldosteronizmas ar antinksčių karcinomos sukeltas PHA [4].

Diagnostika. PHA diagnostikos principas - pacientų atranka, PHA patvirtinimas ir PHA potipiu klasifikavimas. Indikacijos pacientų atrankai - hipertenzija su nustatyta hipokalemija; hipertenzija su nustatyta antinksčių incidentaloma; hipertenzija ir šeiminė ankstyvos hipertenzijos anamnezė arba smegenų insultas jaunesniems nei 40 metų asmenims; pacientams, sergantiems hipertenzija, kurių pirmos eilès giminaičiams diagnozuotas PHA [1]. Atliekant atrankos testus, matuojamos plazmos aldosterono ir renino koncentracijos. PHA galima itarti, kai plazmos aldosterono koncentracija $\geq 10 \mathrm{ng} /$ $\mathrm{dL}$, o plazmos renino aktyvumas $<1 \mathrm{ng} / \mathrm{mL} / \mathrm{h}$. PHA patvirtinimui atliekami aldosterono supresijos mėginiai - dažniausiai peroralinis druskos krūvio testas ir $\mathrm{NaCl}$ infuzijos testas. PHA diagnozė patvirtinama, kai atlikus aldosterono supresijos testą, nuo renino nepriklausoma aldosterono sekrecija nepakinta 
[5]. Potipių klasifikavimui rekomenduojama atlikti kompiuterinès tomografijos (KT) ir antinksčiu veninio kraujo (AVS) tyrimus. Tai leidžia nustatyti PHA priežastį - ar tai vienpusis, ar abipusis procesas, PHA sukèlè antinksčių hiperplazija ar karcinoma. Lateralizacija nustatoma, jeigu AVS tyrimo metu aldosterono (kortizolio) santykis mažiausiai 4 kartus skiriasi tarp skirtingų pusių antinksčių. Abipusès hiperplazijos atveju aldosterono (kortizolio) santykis beveik nesiskiria $[5,6]$.

Gydymas. Pirminio hiperaldosteronizmo gydymo esmè - aldosterono hipersekrecijos ir jo sukeltos hipertenzijos kontrolè bei inkstų ir širdies-kraujagyslių sistemų pažeidimo prevencija. Gydymo taktika pasirenkama priklausomai nuo pirminio hiperaldosteronizmo potipio - vienpusès antinksčio adenomos gydymui taikoma laparoskopinė adrenalektomija, o abipusès antinksčių hiperplazijos atvejais skiriamas medikamentinis gydymas [1,7]. Taikant vienpusę adrenolektomiją, adekvati hipertenzijos kontrolè pasiekiama iki 60 proc. atvejų [8]. Esant abipusei antinksčių hiperplazijai, rekomenduojamas medikamentinis gydymas mineralkortikoidinių receptorių antagonistais - spironolaktonu ar eplerenonu, antro pasirinkimo vaistai - amiloridas ir triamterenas. Jei hipertenzijos nepavyksta kontroliuoti diuretikais, papildomai skiriami AKF inhibitoriai [7].

\section{Išvados}

1. Dažniausios pirminio hiperaldosteronizmo priežastys - abipusė antinksčių hiperplazija ir vienpusé antinksčių adenoma.

2. Pirminio hiperaldosteronizmo diagnostikos principas - pacientų atranka, diagnozės patvirtinimo testai ir pirminio hiperaldosteronizmo potipių klasifikavimas.

3. Gydymo taktiką lemia pirminio hiperaldosteronizmo potipis. Pagrindiniai gydymo metodai - laparoskopinė adrenalektomija arba mineralkortikoidinių receptorių antagonistai.

\section{Literatūra}

1. Funder JW, Carey RM, Mantero F, Murad MH, Reincke M, Shibata $\mathrm{H}$, et al. The management of primary aldosteronism: case detection, diagnosis, and treatment: an Endocrine Society clinical practice guideline. The Journal of Clinical Endocrinology \& Metabolism. 2016;101(5):1889-916.

https://doi.org/10.1210/jc.2015-4061

2. Monticone S, D'Ascenzo F, Moretti C, Williams TA, Veglio F, Gaita $\mathrm{F}$, et al. Cardiovascular events and target organ damage in primary aldosteronism compared with essential hypertension: a systematic review and meta-analysis. Lancet Diabetes Endocrinol 2018;6(1):41-50. https://doi.org/10.1016/S2213-8587(17)30319-4

3. Byrd JB, Turcu AF, Auchus RJ. Primary aldosteronism: a practical approach to diagnosis and management. Circulation 2018;138(8):823-35.

https://doi.org/10.1161/CIRCULATIONAHA.118.033597
4. Young WF, Nieman LK, Martin KA. Pathophysiology and clinical features of primary aldosteronism.UpToDate 2021. https://www.uptodate.com/contents/pathophysiology-andclinical-features-of-primary-aldosteronism?search=hyperald osteronism\&source $=$ search_result\&selectedTitle $=2 \sim 114 \&$ us age_type $=$ default\&display_rank=2\#H283938867

5. Young WF, Nieman LK,Bakris GL, Martin KA. Diagnosis of primary aldosteronism. UpToDate 2021. https://www.uptodate. com/contents/diagnosis-of-primary-aldosteronism?search=hy peraldosteronism\&source $=$ search $\_$result\&selectedTitle $=1 \sim 114$ \&usage_type=default\&display_rank=1\#H2697328494

6. Young WF, Stanson AW, Thompson GB, Grant CS, Farley DR, van Heerden JA. Role for adrenal venous sampling in primary aldosteronism. Surgery 2004;136(6):1227-35.

https://doi.org/10.1016/j.surg.2004.06.051

7. Young WF, Nieman LK, Martin KA. Treatment of primary aldosteronism.UpToDate 2021. https://www.uptodate.com/ contents/treatment-of-primary-aldosteronism?search=hypera ldosteronism\&source $=$ search_result\&selectedTitle $=3 \sim 114 \&$ usage_type $=$ default\&display_rank=3\#H158286814

8. Williams TA, Lenders JWM, Mulatero P, Burrello J, Rottenkolber $\mathrm{M}$, Adolf C, et al. Outcomes after adrenalectomy for unilateral primary aldosteronism: an international consensus on outcome measures and analysis of remission rates in an international cohort. Lancet Diabetes Endocrinol 2017;5(9):689-99.

https://doi.org/10.1016/S2213-8587(17)30135-3

\section{PRIMARY HYPERALDOSTERONISM: ETIOLOGY, DIAGNOSIS AND TREATMENT D. Savičius}

Keywords: aldosterone, primary hyperaldosteronism, etiology, diagnosis and treatment of PHA.

Summary

Primary hyperaldosteronism is estimated to be a primary cause of hypertension in up to $>10 \%$ of patients. Primary hyperaldosteronism is associated with a higher rate of cardiovascular morbidity and mortality when compared with age- and sex-matched patients with primary hypertension. The main principle of diagnosis of primary hyperaldosteronism - case-detection testing, case confirmation and subtype classification. The treatment goal in patients with primary aldosteronism is to stabilize blood pressure and hypersecretion of aldosterone, and to prevent the mortality associated with hypertension, renal and cardiovascular damage. The aim of this study was to evaluate, systematize and analyze the data presented in the scientific literature on etiology, diagnosis and treatment of primary hyperaldosteronism.

Conclusions. 1. The most common causes of primary hyperaldosteronism are bilateral adrenal hyperplasia and unilateral adrenal adenoma. 2. The main principle of diagnosis of primary hyperaldosteronism - case-detection testing, case confirmation and subtype classification. 3. Treatment approach is based upon the subtype of hyperaldosteronism. Main methods of treatment include laparoscopic adrenalectomy or mineralocorticoid receptor antagonist therapy.

Correspondence to: donatassavicius@gmail.com

Gauta 2021-04-28 